\title{
Agency costs, corporate governance mechanisms and performance of public listed family firms in Malaysia
}

\author{
H. Ibrahim* \\ School of Management, Universiti Sains Malaysia, \\ 11800 USM, Penang, Malaysia \\ haslindar@usm.my \\ F.A. Samad \\ Faculty of Business and Accountancy, University of Malaya, \\ 50603 Kuala Lumpur, Malaysia \\ mfazilah@um.edu my
}

Received June 2009

\begin{abstract}
We compare corporate governance and performance between family and non-family ownership of public listed companies in Malaysia from 1999 through 2005 measured by Tobin's Q and ROA. We also examine the governance mechanisms as a tool in monitoring agency costs based on asset utilization ratio and expense ratio as proxy for agency costs. We find that on average firm value is lower in family firms than non-family firms, while board size, independent director and duality have a significant impact on firm performance in family firms as compared to non family firms. We also find that these governance mechanisms have significant impact on agency costs for both family and non family firms.
\end{abstract}

*To whom all correspondence should be addressed.

\section{Introduction}

The family-controlled firm or family ownership is the most common form of business organization in the world. A various stream of literature explains that family ownership is central in most countries. La Porta, Lopez-De-Silanes, and Shleifer (1999) studied the 20 largest publicly traded companies in the richest 27 countries worldwide and found most companies are private and the ownership of listed firms is highly concentrated which highlighted family ownership as a significant corporation. The family-owned or controlled businesses account for over 80 percent of all firms in the U.S. Indeed, families are present in one third of the S\&P 500 and hold nearly 18 percent of firms' equity stake (Anderson \& Reeb, 2003).

Ownership structure has been widely debated since Berle and Means (1932). According to Jensen (2000), ownership structure is significant in determining firms' objectives, shareholders wealth and the disciplined of manager. Both managers and shareholders should have a single objective of maximizing firm value.

The objective of the study is to investigate the impact of corporate governance mechanisms such as board size, independent director and duality on performance, as a tool in mitigating an agency costs between family and non family firms in Malaysia. The comparison of performance between the Malaysian family and non-family firms is a significant research and value-added to the existing empirical studies. By adapting, identifying and classifying the family firms from the main board, this paper has transparently reveal the sensitivity and the uniqueness of the Malaysian family business culture.

In Malaysia, family ownership constitutes over 42 percent of the main board companies of the Bursa Malaysia (formerly known as the Kuala Lumpur Stock Exchange (KLSE)) from 1999 through 2005 yet studies examining the performance of family ownership are very limited specifically in the area of corporate governance and agency costs. Our results showed that on average, family firms experience lower agency costs as compared to non-family firms based on the asset utilization ratio and expense ratio using agency cost proxies. Meanwhile, board size, independent director and duality for family ownership has a strong significant influence on firm performance. This is consistent with previous studies by Ang, Cole and Lin (2000), McKnight and Mira (2003), and Jensen and Meckling (1976).

\section{Literature review}

\section{Family ownership In Malaysia}

Family ownership is very significant in developing and building a country. According to Claessens, Djankov and Lang (2000) studies of the separation of ownership and control in nine East Asian corporations (Hong Kong, 
Indonesia, Japan, South Korea, Malaysia, Philippines, Singapore, Taiwan and Thailand), Malaysia is the third highest concentration of control after Thailand and Indonesia. Family ownership in Malaysia increases from 57,7 percent to 67,2 percent as the cut off level of voting right increases from 10 percent to 20 percent.

Jasani (2002) finds that Small and Medium Scale Enterprises (SME) are managed by the founder and anchored to the family in terms of funding and employment. Indeed, the firms are conducted by the founder with activities concentrating on trading, manufacturing and retailing. He finds that 59 percent, that is the majority of the businesses in Malaysia, are still managed by the founder while 30 percent are run by the second generation where the majority are the founder's children. The founder's reign is highlighted with 65 percent of them linked to the SME.

In addition, the list of the 40 richest Malaysians 2009 is obviously dominated by family as issued by the Malaysian Business in February 2009 edition. From the list, 28 out of the 40 richest people are family based and account for 70 percent of the top 40. According to the top 40 list of Malaysia's richest people, Tan Sri Robert Kuok appears to dominate the chart and he was well ahead of his rivals. His outstanding wealth accounted for RM26.6 billion or 27.6 percent of the wealth of the 40 richest declining from RM58.1 billion in 2008, however no other tycoon is yet able to unseat him as the country's wealthiest individual (Singh, 2009).

\section{Corporate Governance and Firms Performance}

Denis and McConnell (2003) define corporate governance as the set of mechanisms, for both institutional and market based, that influence the self-interested controllers of a firm (those that make decisions regarding how the firm will be operated) to make decisions that maximize the value of the firm for its owners (the suppliers of capital). The influence of the board size and composition are significant to board involvement in corporate affairs. Singh and Davidson (2003) state that the size and composition of the board may reflect its ability to be an efficient guide and their findings show that firm performance is increased by smaller boards, which are consistent with Hermalin and Weisbach (2003), Jensen (1993) and Lipton and Lorsh (1992).

In addition, Fama and Jensen (1983) explain that board outsiders could strengthen the firm's value by lending experience and monitoring services. Outside directors are supposed to be guardians of the shareholders' interests via monitoring. Hermalin and Weishbach (1991) and Coughlan and Schmidt (1985) support the argument that outside directors are more effective monitors and a critical disciplining device for managers. Lee, Rosenstein, Rangan, and Davidson (1992) and Byrd and Hickman (1992) explain a positive relationship between performance and outsiders' proportion. Meanwhile, Klein, Shapiro, and Young (2005), Subrahmanyam, Rangan, and Rosenstein (1997), and Agrawal and Knoeber (1996) find that board independence is in fact negatively correlated with performance. Hermalin and Weishbach (1991) posit no significant relationship between performance and outsiders' proportion on the board of directors.

Duality can be defined as a board structure control mechanism which is explained as the same person serving as both the chief executive officer (CEO) and chairman of the board. Previous studies analyzing the impact of duality on firm performance have been mixed. As such, Weir, Laing, and McKnight, (2002) find that duality shows no role as to enhancing firm performance in the U.K firms whereas in the U.S studied by Boyd (1994) finds that duality actually bring to better performance. McKnight and Mira (2003) find that duality had a moderately strong and negative impact on quality values. In other words, firms where duality did exist performed poorly with respect to those firms where CEO did not occupy both positions

\section{Corporate governance and agency costs}

Agency costs occur from the misalignment of interests between the firm's managers and the firm's shareholders. This conflict of interest between manager and shareholders is caused by the physical presence of excess cash or cash equivalents (Jensen \& Meckling, 1976). There are few studies that examine the relationship between agency costs and board structure and ownership characteristics. Singh and Davidson (2003) reveal that a board with small size has a positive and significant influence on asset utilization efficiency showing that higher asset utilization efficiency indicates lower agency costs. The results are consistent with Florackis and Ozkan's (2004) findings, which show that board size has a negative coefficient in relation to asset turnover, indicating that larger board sizes are less efficient (Beiner et al., 2004; Eisenberg, Sundgren \& Wells, 1998).

The presence of outside directors on the board is perceived as a governance mechanism that could help in monitoring the agency problem. Consequently, Jensen (1993) and Berle and Means (1932) open the debate as to whether nonexecutive directors promote shareholders interest. Some researchers explained that non-executive directors are more likely to align themselves with top management rather than the shareholders. This is not due to top managers having a strong influence over who is on the board (Hermalin \& Weishbach, 1998; Byrd \& Hickman, 1992), but because non-management directors typically hold an unimportant portion of the firm's stock (Rhoades \& Rechener, 2000; Brickly, Coles \& Terry, 1994; Patton \& Baker, 1987). However, Florackis and Ozkan (2004) and McKnight and Mira (2003) find evidence that duality has no influence on agency costs.

\section{Data and methodology}

A total of 474 companies were listed on the main board of the Bursa Malaysia as at 31 December 1999. All financial and unit trust companies were omitted from the study because of differences in regulatory requirements. In addition, the study excluded companies which fail to comply with any obligations under Practice Note such as Practice 
Note 4 (PN4) $^{1}$ and Practice Note $17(\mathrm{PN} 17)^{\mathrm{a}}$ and also companies with incomplete data. As a result we selected 2030 observations for 290 companies across seven years from 1999 to 2005 as our sample. The data was taken from the annual reports and financial databases such as Worldscope, Datastream, and Perfect Analysis. As a longitudinal study, it is important to ensure that all companies were active for the entire period of the study. Therefore, this study implements non-probability sampling by using the judgment method to select sample members to fit to some criterion (Cooper \& Schindler, 2001).

We classify family firms based on two criteria. The first criterion is the presence of a family member on the board, which has been used by Yammeesri and Lodh (2004), Anderson and Reeb (2003) and Yeh, Lee \& Woidtke et al. (2001) to identify family firms. Then, the second criterion is that family members must hold at least 20 percent of outstanding equity stake as the cut off level benchmark as used by Sraer and Thesmar (2006), Favero, Giglio and Honorati (2006), La Porta et al. (1999) and Berle and Means (1932). In order to be selected as family ownership, the selected firm must fulfill either one or both of these criteria. Meanwhile, the study categorizes the sample as non-family ownership when the firm does not meet the criteria used in determining family ownership.

The study used market measure such as Tobin's Q which is computed as the ratio of the market capitalization plus total debt divided by total asset of the company. Also, accounting measures such as Return on Assets (ROA) which is the ratio of net income divided by the total assets. The higher the $\mathrm{Q}$ value means the more effective the governance mechanisms of the company. It also indicates that the market's perception of the company performance is good (Weir et al., 2002). In addition, higher ROA shows the company uses its asset effectively in serving shareholders' economic interests.

This study applied two types of agency cost proxies (the asset utilization ratio (AC1) and expense ratio (AC2)) to analyze the relationship between agency costs and corporate governance between family and non-family ownership. The asset utilization ratio or asset turnover ratio is annual sales divided by total assets. The asset utilization ratio measures how effectively the management of the company uses or organizes its assets. The company who experiences low asset utilization ratio indicates high agency costs meaning an inverse relationship to each other. This proxy for agency costs has been adopted by Florackis and Ozkan (2004), Singh and Davidson (2003) and Ang et al. (2000).

The expense ratio as measured by operating expense divided by annual sales. This study adopts the agency costs proxy as used previously by Ang and Ding (2005) and Ang et al. (2000). This efficiency ratio measures how effectively the management of the company controls operating costs such as expenses on the luxury automobiles or company

\footnotetext{
${ }^{1}$ PN4 and PN17 are the criteria and obligations pursuant to paragraph 8.14 and $8.14 \mathrm{c}$ respectively of the listing requirements in the Bursa Malaysia. Both PN4 and PN17 occur when the firms having financial difficulties. PN4 is further amended to PN17 with effect on 3 January 2005 .
}

furniture, and also other direct agency costs. In contrast to the asset utilization ratio, agency costs are positively related to expense ratio. It indicates that a high expense ratio experiences high agency costs.

Several control variables used to control for companies characteristics such as firm size, firm risk and firm age. Firm size is the natural log of total asset (lnasset) of the company. We also control for companies debt ratio as a firm leverage (Leverage) by calculating total debt over total asset of the company. Firm age (Age) is measured as the number of years since the company is incorporated.

In this analysis, the data will be testified to establish which estimation of panel data regression is appropriate by using the Pooled Ordinary Least Squared (OLS), the Fixed and the Random effects approach. Both the Fixed and Random effects approach use the Redundant Fixed EffectsLikelihood Ratio and Correlated Random Effects-Hausman Tests to testify the significance of the Fixed and Random Effects model. Finally, the Fixed effect approach has been selected as the most appropriate model for this study. Thus we develop the following model in the study to analyze the relationship between corporate governance and agency cost for both family and non-family ownership.

Thus, we develop the two following models in the study: Model 1 to analyze the relationship between corporate governance and performance for both family and non-family ownership; Model 2 to analyze the relationship between corporate governance mechanisms and agency costs for both family and non-family ownership.

Model 1

Firm value $=\quad \begin{aligned} & \alpha_{0}+\beta_{1} \text { Lev }+\beta_{2} \text { Age }+\beta_{3} \text { Lnasset }+ \\ & \beta_{4} \text { Bsize }+\beta_{5} \text { OutDir }+\beta_{6} \text { Duality }+\varepsilon\end{aligned}$

Model 2

Agency costs $=\begin{aligned} & \alpha_{0}+\beta_{1} \text { Lev }+\beta_{2} \text { Age }+\beta_{3} \text { Lnasset }+ \\ & \beta_{4} \text { Bsize }+\beta_{5} \text { OutDir }+\beta_{6} \text { Duality }+\varepsilon\end{aligned}$

\section{Results and discussion}

\section{Descriptive statistics}

Table 1 presents the descriptive statistics for full and individual sample for family and non family ownership in Malaysia. On average, Tobin's Q shows that non-family ownership has greater valuations than family ownership, 1,069 versus 0,788 for non-family and family ownership respectively and statistically significant at 1 percent level $(\rho<0,01)$. The result is consistent with Favero et al. (2006), Barontini and Caprio (2005) and Yeh et al. (2001) who find that, as measured by Tobin's Q, founding family heir, family with professional CEO, and family with low level of control underperform non-family firms. With respect to ROA, family ownership has a lower value than non family, 2,6 percent versus 3.6 percent for family and non-family ownership respectively but not statistically significant at 1 percent level consistent with the findings of Mishra, Randoy and Jenssen (2001). 
In addition, on average, the mean value of asset utilization ratio for non-family ownership is higher with a value of 81.3 percent compared to family ownership of 55.9 percent. This finding suggests that non-family ownership experiences low agency costs as the higher the asset utilization ratio indicates low agency cost of the firms. Yet, there is no evidence of a significant difference in means between the groups. Further examination of the comparisons reveal that family ownership experiences low agency costs with the average expense ratio of family at 31.2 percent, which is slightly lower than non-family ownership at 32.0 percent. In this case, low expense ratio indicates low agency costs. However, these mean differences for both agency costs proxies are not statistically significant.

For corporate governance structure, we found that board size for all samples, family and non family ownership is similar with an average of 8 persons on board. The independent director shows a significant difference in mean between family and non family. Meanwhile, the frequency of the duality shows that only 6.5 percent of the samples have not separated the role of chairman and CEO on the board.

The descriptive statistics show an average value of leverage for the full sample of 26.0 percent while the leverage ratio for family and non-family are 25.6 percent and 26.2 percent respectively. The results show that the family ownership uses less debt, however, family firms do not appear to use debt differently than non-family, which is consistent with the findings of Sraer and Thesmar (2006), Barontini and Caprio (2005), Anderson and Reeb (2003), and Mishra et al. (2001).

The average of firm age in all samples of the study is nearly 30 years old, ranging from three to 95 years old and is not statistically significant different between family and nonfamily ownership in this sample. In addition, the statistics also show that an average value of total assets for all firms amounts to RM1,936.36 million. The data includes very small companies as well as large companies with a mean value of total assets of RM56,964.96 million and RM21,29 million respectively. In relation to ownership structure, on average, family ownerships are smaller than non-family ownership but still of large size with average total assets of RM1,700.71 million relative to RM2,114.88 million, and statistically insignificantly different in mean.

In comparing the average value of market capitalization between family and non-family ownership, the results show that non-family has RM1,326.39 million more market value than family, which amounts to RM803,38 million. However, this result shows that there is no evidence of statistically significant differences in means for risk or leverage, age, total assets and market capitalization between family and non-family $(\rho>0,01)$.

Table 2 presents the correlation matrix for the dependent and independent variables. Firm value as measured by Tobin's Q and ROA appear to bear a negative and positive relationship to board size and a positive and negative relationship to independent directors of the company. The results are consistent with a study on corporate governance and performance of Malaysian listed companies by Haniffa and Hudaib (2006). In addition, the presence of family ownership causes Tobin's q to have a significant negative relationship with duality but a significant positive relationship with independent directors. While a negative and not significant relationship is observed between family ownership and board size. This is consistent with studies by Mishra et al. (2001) and Yermack (1996) on Norwegian and US family firms, respectively.

\section{Corporate governance mechanisms and firm performance}

Next we analyzed the relationship between corporate governance mechanisms and performance of family and non family ownership in Malaysia using Tobin's Q and ROA as performance measures. Generally, board size of individual ownership of family and non-family in Malaysia is found to be significantly negatively related to Tobin's Q. This result is consistent with Haniffa and Hudaib (2006) and Mak and Yuanto (2002) who conducted a similar research on Malaysian listed companies. It implies that companies with a small board of directors accomplish higher values in the capital markets and are also more profitable than their counterparts with a large board of directors.

Interesting results are found between family and non-family ownership concerning the relationship between outside directors and performance. For family ownership, the results show a significantly negative relationship between the fraction of outside directors and firm performance based on ROA. The results are supported by Anderson and Reeb (2003), Mishra et al. (2001), Subrahmanyam et al. (1997), and Agrawal and Knoeber (1996). It indicates that firm performance is decreased as outside directors are added to the board. More specifically, family firms may require a prudent balance between the objectivity of independent directors and the interests of family directors in order to pursue family members' interest. In addition, according to Finkelstein and Hambrick (1996), board outsiders may lack the firm specific expertise of insiders and family members that could lead to poor strategic decisions.

In contrast, firms with non-family ownership have a significant positive relationship between the fraction of independent directors and performance based on Tobin's Q and ROA. This evidence is consistent with the view that outside directors improve board effectiveness and firm performance because of their efficiency in monitoring managers (Adams \& Mehran, 2003; Brickley et al., 1994). It indicates that non-family ownership prefers a higher presence of independent directors who could bring in their prestige, expertise and contacts to the firms (Grace, Ireland \& Dunstan, 1995; Kesner \& Johnson, 1990). Additionally, outside directors could influence the quality of decisions and thoughtfulness in providing a strategic direction for the companies (Pearce \& Zahra, 1992). 
Table 1: Descriptive statistics and differences of mean test of family ownership and non family ownership in Malaysia for year 1999 to 2005

\begin{tabular}{|c|c|c|c|c|c|}
\hline \multirow[t]{2}{*}{ Variables } & \multicolumn{2}{|l|}{$\begin{array}{l}\text { Full Sample } \\
(\mathbf{N}=\mathbf{2 9 0})\end{array}$} & \multirow{2}{*}{$\begin{array}{l}\text { Family } \\
(\mathrm{N}=125) \\
\text { Mean }\end{array}$} & \multirow{2}{*}{$\begin{array}{l}\text { Non Family } \\
\text { (N=165) } \\
\text { Mean }\end{array}$} & \multirow{2}{*}{$\begin{array}{l}\text { t-statistics of } \\
\text { Differences }\end{array}$} \\
\hline & Mean & Std. Dev & & & \\
\hline \multicolumn{6}{|l|}{ Performance Measures: } \\
\hline Return on Asset (ROA) (Accounting & 0,948 & 0,991 & 0,788 & 1,069 & $-2,697 *$ \\
\hline Measures) & 0,032 & 0,249 & 0,026 & 0,036 & $-0,350$ \\
\hline \multicolumn{6}{|l|}{ Proxies for Agency Costs: } \\
\hline Asset Utilization Ratio (AC1) & 0,703 & 2,482 & 0,559 & 0,813 & $-0,862$ \\
\hline Expense Ratio (AC2) & 0,317 & 0,598 & 0,310 & 0,322 & $-0,167$ \\
\hline \multicolumn{6}{|l|}{ Board Structure: } \\
\hline \multicolumn{6}{|l|}{ Board Size (Number of person) } \\
\hline (BSIZE) & 8 & 1,875 & 8 & 8 & 0,373 \\
\hline $\begin{array}{l}\text { Independent Director (fractional) } \\
\text { (OUTDIR) }\end{array}$ & 0,385 & 0,088 & 0,361 & 0,403 & $-4,341 *$ \\
\hline \multicolumn{6}{|l|}{ Control Variables } \\
\hline Firm Leverage (LEV) & 0,260 & 0,255 & 0,256 & 0,262 & $-0,199$ \\
\hline Firm Age (years) & 29,617 & 17,798 & 29,2 & 29,8 & $-0,280$ \\
\hline Firm Size (total asset) ('000) & $1,936,356,6$ & $4,517,151,2$ & $1,700,708,6$ & $2,114,877,7$ & $-0,773$ \\
\hline Market Capitalization ('000) & $1,100,952,6$ & $3,189,398,3$ & $803,379,0$ & $1,326,387,1$ & $-1,524$ \\
\hline Percentage of Duality in sample: & $\underline{\text { Non-Duality }(0)}$ & Duality (1) & & & \\
\hline Full Sample & $93,5 \%$ & $6,5 \%$ & & & \\
\hline Family & $87,5 \%$ & $12,5 \%$ & & & \\
\hline Non-Family & $98,2 \%$ & $1,8 \%$ & & & \\
\hline
\end{tabular}

* Significant at 0,01 level

Table 2: Correlation matrix

\begin{tabular}{|c|c|c|c|c|c|c|c|c|c|c|c|}
\hline & $\mathbf{Q}$ & ROA & AC1 & AC2 & LEV & $\begin{array}{c}\text { LN } \\
\text { ASSET }\end{array}$ & AGE & BSIZE & OUTDIR & DUALITY & FAMILY \\
\hline $\mathrm{Q}$ & 1 & & & & & & & & & & \\
\hline ROA & 029 & 1 & & & & & & & & & \\
\hline $\mathrm{AC} 1$ & 021 & 009 & 1 & & & & & & & & \\
\hline $\mathrm{AC} 2$ &,- 020 &, $130 *$ &,- 060 & 1 & & & & & & & \\
\hline LEV &, $446 * *$ &,$- 143 *$ & ,003 & ,086 & 1 & & & & & & \\
\hline LNASSET &,$- 281 * *$ &,- 039 & ,016 &,- 081 &,- 021 & 1 & & & & & \\
\hline AGE & ,112 &,- 051 &,- 100 & ,091 &, 058 &,- 019 & 1 & & & & \\
\hline BSIZE &,- 064 & ,038 &, 042 &,- 091 &,$- 145 *$ &, $378 * *$ &,$- 150 *$ & 1 & & & \\
\hline OUTDIR &, 007 &,- 012 &,- 045 & ,086 &, 100 &,- 019 &, $215 * *$ &,$- 400 * *$ & 1 & & \\
\hline DUALITY &, 004 &,- 027 &,- 015 & 019 & ,038 &, 108 &,- 005 &, 003 &,- 003 & 1 & \\
\hline FAMILY &,$- 134 *$ &,- 021 &,- 050 &,- 007 &,- 010 &,- 009 &,- 009 & ,016 &,$- 235^{* * *}$ &, $261 * *$ & 1 \\
\hline
\end{tabular}

** significant at 0,01 level (2-tailed).

* significant at the 0,05 level (2-tailed).

The role of duality is one of the corporate governance mechanisms and previous studies have raised this issue due to their belief that duality could make a difference to corporate governance and performance (Anderson \& Anthony, 1986; Alibrandi, 1985). Generally, the duality role of firms with family ownership is found to be significantly negatively related to Tobin's Q and ROA, which is consistent with Haniffa and Hudaib (2006) and McKnight and Mira (2003). It suggests that the existence of a duality role on the board could lead to poor performance compared to firms where both positions are separated.
In contrast, duality in firms with non-family ownership is significantly positively related with ROA. This finding is confirmed by Sridharan and Marsinko (1997) who find that firms with the existence of a duality role experience higher profitability and may also avoid some costs of conflict between the CEO and the board by having strong consistent leadership at the top. In addition, when more power is held by one person it may lead to better decisions and directly improve firm performance (Rechner \& Dalton, 1991; Donaldson \& Davis, 1991). 
Table 3: Corporate governance and performance of family and non-family ownership in Malaysia

\begin{tabular}{|c|c|c|c|c|}
\hline \multirow[b]{2}{*}{ Variables } & \multicolumn{2}{|c|}{ Tobin's Q } & \multicolumn{2}{|c|}{ ROA } \\
\hline & $\begin{array}{l}\text { Family } \\
(\mathrm{N}=125)\end{array}$ & $\begin{array}{c}\text { Non Family } \\
(\mathrm{N}=165)\end{array}$ & $\begin{array}{l}\text { Family } \\
(\mathrm{N}=125)\end{array}$ & $\begin{array}{c}\text { Non Family } \\
(\mathrm{N}=165)\end{array}$ \\
\hline Intercept & $3,047(16,101)^{* * *}$ & $5,563(19,694) * * *$ & $0,098(2,341)^{* *}$ & $0,342(3,803) * * *$ \\
\hline \multicolumn{5}{|l|}{ Board Structure: } \\
\hline Board Size & $-0,013(-3,614) * * *$ & $-0,008(-1,907)^{*}$ & $-0,001(-0,795)$ & $0,001 \quad(0,930)$ \\
\hline Independent Director & $-0,026(-0,551)$ & $0,102(1,717)^{*}$ & $-0,039(-3,497) * * *$ & $0,052(2,649) * * *$ \\
\hline Duality & $-0,044(-1,753)^{*}$ & $0,049(0,731)$ & $-0,024(-2,169) * *$ & $0,050(2,156)^{* *}$ \\
\hline \multicolumn{5}{|l|}{ Control Variables: } \\
\hline Firm Leverage & $0,673(17,862)^{* * *}$ & $0,596(18,518)^{* * *}$ & $-0,121(-11,017)^{* * *}$ & $-0,187(-14,576) * * *$ \\
\hline Firm Age (years) & $-0,015(-8,984) * * *$ & $-0,024(-10,097) * * *$ & $0,0001(0,235)$ & $-0,004(-4,857)^{* * *}$ \\
\hline Firm Size (lnasset) & $-0,139(-10,510) * * *$ & $-0,289(-14,359) * * *$ & $-0,002(-0,448)$ & $-0,013(-1,946)^{*}$ \\
\hline Observation & 875 & 1155 & 875 & 1155 \\
\hline R-Squared & 0,850 & 0,895 & 0,716 & 0,754 \\
\hline Adjusted R-Squared & 0,824 & 0,877 & 0,666 & 0,712 \\
\hline F-stat (p-value) & $32,551(p=0,00)$ & $49,435(p=0,00)$ & $14,434(p=0,00)$ & $17,752(p=0,00)$ \\
\hline
\end{tabular}

\section{Corporate governance mechanisms and agency costs}

Table 4 presents the findings of the relationship between corporate governance and agency costs. Instead of examining the relationship between corporate governance and agency costs, the study also investigates this effect for different types of ownership - family and non-family. According to Miller and Le Breton-Miller (2006), they construe that family firms differ in the degree to which they have to bear these costs relying on their governance choices.

In this analysis, the study finds that both family and nonfamily reveal similar results, which are significantly positively related with regards to the relationship between board size and asset utilization ratio (AC1). This result supports the findings of Singh and Davidson (2003) who finds evidence that board size is significantly positively related to the asset utilization ratio, which leads to lower agency costs. As a result, there is strong evidence that board size has a significant effect as a device in reducing agency costs by increasing the number of members on the board. Moreover, the board of directors must be composed of valuable and knowledgeable persons who can give advice, counsel, and as a channel for communicating information between external organizations and the firm (Pfeffer \& Salancik, 1978).

The proportion of independent directors is significantly positively related to the asset utilization ratio, but not significant to the expense ratio for non-family firms. But for family firms, the results are in the opposite direction to non family, which is negatively (positively) related to asset utilization ratio (expense ratio), but not statistically significant. The result indicates that the effect of corporate governance differs with the ownership type. It shows that firms with non-family ownership prefer more independent directors on the board as this may bring in expertise, experience, contacts and contracts, but is often more specifically for political reasons, legitimacy and reputation (Haniffa \& Hudaib, 2006; Pfeffer \& Salancik, 1978). Conversely, family ownership does not rely on outside directors, which maybe due to outside directors lacking knowledge about the family firm's specific interests and consequently be detrimental to the firm's strategic mission.

In relation to the role of duality, firms with family ownership have significantly positively related to asset utilization ratio, but the relationship is not significant with the expense ratio. The results indicate that firms with duality practice could increase the asset utilization ratio thus, having less agency conflict. In fact, firms with a high asset utilization illustrate that firms have generated a large amount of sales, and, definitely cash flow for a given level of their assets. Generally, there is strong evidence that firms with a duality role experience less agency conflicts (Singh \& Davidson, 2003).

Conversely, non-family ownership with duality role is significantly positively related to expense ratio, but not significant to asset utilization ratio. The results show that the existence of a duality role on the board increases the expense ratio, indicating that these firms experience high agency costs. This finding is further supported by Fama and Jensen (1983) who argue that if the role of duality is separated on the board, it could mitigate agency conflict.

\section{Conclusion}

Our main objective in this study is to investigate the relationship between corporate governance and agency costs between family and non family firms. We found that on average, family firms have lower agency costs as compared to non family ownership but on a minus side, they have lower firm value. In addition, family ownership can further mitigate agency problems by increasing the number of 
directors on board and adopting the role of duality. For non family ownership, instead of having a larger board, the number of independent directors and duality role should be increased and separated respectively towards reducing agency costs. Our study further confirmed Malaysian firms especially family ownership are sensitive towards agency costs and corporate governance mechanisms.

Table 4: Agency cost and corporate governance of family and non-family ownership in Malaysia

\begin{tabular}{|c|c|c|c|c|}
\hline \multirow[b]{2}{*}{ Variables } & \multicolumn{2}{|c|}{ Asset Utilization Ratio (AC1) } & \multicolumn{2}{|c|}{ Expense Ratio (AC2) } \\
\hline & $\begin{array}{l}\text { Family } \\
(\mathrm{N}=125)\end{array}$ & $\begin{array}{c}\text { Non Family } \\
(\mathrm{N}=165)\end{array}$ & $\begin{array}{l}\text { Family } \\
(\mathrm{N}=125)\end{array}$ & $\begin{array}{c}\text { Non Family } \\
(\mathrm{N}=165)\end{array}$ \\
\hline Intercept & $1,517(15,151)^{* * *}$ & $-0,525(-2,785)^{* * *}$ & $1,138(4,836)^{* * *}$ & $1,581(11,090)^{* * *}$ \\
\hline \multicolumn{5}{|l|}{ Board Structure: } \\
\hline Board Size & $0,005(2,249) * *$ & $0,025(5,566)^{* * *}$ & $0,005(1,543)$ & $0,002(1,099)$ \\
\hline Independent Director & $-0,030(-0,968)$ & $0,508(7,225)^{* * *}$ & $0,042(0,887)$ & $0,021(0,633)$ \\
\hline Duality & $0,021(1,656)^{*}$ & $-0,060(-0,971)$ & $-0,068(-1,384)$ & $0,058(1,815)^{*}$ \\
\hline \multicolumn{5}{|l|}{ Control Variables: } \\
\hline Firm Leverage & $-0,081(-3,838)^{* * *}$ & $-0,107(-3,224) * * *$ & $0,130(3,216)^{* * *}$ & $-0,009(-0,430)$ \\
\hline Firm Age (years) & $0,014(12,021)^{* * *}$ & $0,032(13,718)^{* * *}$ & $0,015(10,917)^{* * *}$ & $0,019(15,139)^{* * *}$ \\
\hline Firm Size (lnasset) & $-0,102(-11,950)^{* * * *}$ & $0,0004(0,030)$ & $-0,100(-5,373)^{* * *}$ & $-0,138(-12,157)^{* * *}$ \\
\hline Observation & 875 & 1155 & 875 & 1155 \\
\hline R-Squared & 0,686 & 0,740 & 0,663 & 0,708 \\
\hline Adjusted R-Squared & 0,673 & 0,730 & 0,605 & 0,657 \\
\hline F-stat (p-value) & $162,577(p=0,00)$ & $90,619(p=0,00)$ & $11,278(p=0,00)$ & $14,001(p=0,00)$ \\
\hline
\end{tabular}

$* * *$ Significant at the $1 \%$ level. ** Significant at the 5\% level. * Significant at the $10 \%$ level.

$t$-statistics are in parentheses

\section{References}

Adams, R. \& Mehran, H. 2003. Is corporate governance different for bank holding companies? Working Paper of the Federal Reserve Bank of New York.

Agrawal, A. \& Knoeber, C.R. 1996. 'Firm performance and mechanisms to control agency problems between managers and shareholders', Journal of Financial and Quantitative Analysis, 31: 377-397.

Alibrandi, J.F. 1985. 'A CEOs dream board.' In Nattar, E \& Ball, M. (Eds.). Handbook for corporate directors, New York: McGraw-Hill, 23.1-23.5.

Anderson, C.A. \& Anthony, R.N. 1986. The new corporate directors. New York: John Wiley and Sons.

Anderson, R.C. \& Reeb, D.M. 2003. 'Founding-family ownership and firm performance: Evidence from the S\&P 500', The Journal of Finance, 58(3): 1301-1328.

Ang, J., Cole, R. \& Lin, J. 2000. 'Agency costs and ownership structure', Journal of Finance, 55(1): 81-106.

Ang, J.S. \& Ding, D.K. 2005. 'Government ownership and the performance of government-linked companies: The case of Singapore', Journal of Multinational Financial Management, 6: 37-62.
Barontini, R. \& Caprio, L. 2005. The effect of family control on firm value and performance: Evidence from Continental Europe. ECGI Finance Working Paper No 88/2005, [Online]URL:http://ssrn.com/abstract=675983.

Beiner, S., Drobetz, W., Schmid, F. \& Zimmermann, H. 2004. An integrated framework of corporate governance and firm valuation: Evidence from Switzerland. ECGI Paper $34 / 2004$

Berle, A. \& Means, G. 1932. The modern corporation and private property. New York: MacMillan.

Boyd, B. 1994. 'Board control and CEO compensations', Strategic Management Journal, 15: 335-344.

Brickley, J.A., Coles, J.L. \& Terry, R.L. 1994. 'Outside directors and the adoption of poison pills', Journal of Financial Economics, 34: 371-390.

Bryd, J.W. \& Hickman, K.A., 1992. 'Do outside directors monitor managers?', Journal of Financial Economics, 32: 195-221.

Claessens, S., Djankov, S. \& Lang, L.H.P. 2000. 'The separation of ownership and control in East Asian corporations', Journal of Financial Economics, 58: 81-112 Cooper, D.R. \& Schindler, P.S. 2001. Business research method, $7^{\text {th }}$ Edition. Singapore: Irwin/McGraw Hill Publication. 
Coughlan, A. \& Schmidt, R., 1985. 'Executive compensation, management turnover, and firm performance: An empirical investigation', Journal of Accounting and Economics, 7: 43-66.

Dennis, D. \& McConnell, J.J. 2003. 'International corporate governance', Journal of Financial and Quantitative Analysis, 38: 1-36.

Donaldson, L. \& Davis, J. H. 1991. 'Stewardship theory or agency theory: CEO governance and shareholder returns', Australian Journal of Management, 16(1): 49-95.

Eisenberg, T., Sundgren, S. \& Wells, M. 1998. 'Larger board size and decreasing firm value in small firms', Journal of Financial Economics, 48: 35-54.

Fama, E.F. \& Jensen, M.C. 1983. 'Agency problems and residual claims,' Journal of Law and Economics, 26: 327350 .

Favero, C.A., Giglio, S.W., Honorati, M., \& Panunzi, F. 2006. 'The performance of Italian family firms'. ECGI Working Paper No. 127/2006, [online] URL:http://ssrc.com/abstract_id=918181.

Finkelstein, S. \& Hambrick, D. 1996. Strategic leadership: Top executives and their effects on organizations. Minneapolis-St. Paul: West Publishing.

Florackis, C. \& Ozkan A. 2004. Agency Costs And Corporate Governance Mechanisms: Evidence For UK Firms. Working Paper, University of York, UK.

Grace, M., Ireland, A. \& Dunstan, K. 1995. 'Board composition, non-executive directors' characteristics and corporate financial performance,' Asia-Pacific Journal of Accounting, 17: 121-158.

Haniffa, R. \& Hudaib, M. 2006. 'Corporate governance structure and performance of Malaysian listed companies', Journal of Business Finance and Accounting, 33(7-8): 10341062.

Hermalin, B.E. \& Weisbach, M.S. 1991. 'The effects of board composition and direct incentives on firm performance', Financial Management, 20: 101-112.

Hermalin, B.E. \& Weisbach, M.S. 1998. 'Endogenously chosen boards of directors and their monitoring of the CEO', The American Economic Review, 88(1): 96-118.

Hermalin, B.E. \& Weisbach, M.S. 2003. 'Boards of directors as an endogenously determined institution: A survey of the economic literature', Economic Policy Review, April: 7-25.

Jasani, N.K., 2002. Malaysia's family businesses: The family \& the business international survey report. Malaysia: Shamsir Jasan,i Grant Thorton \& Malaysian Institute of Management, 1-8.
Jensen, M.C. \& Meckling, W.H. 1976. 'Theory of the firm: Managerial behavior, agency costs, and ownership structure', Journal of Financial Economics, 3(4): 305-360.

Jensen, M.C. 1993. 'The modern industrial revolution, exit, and the failure of internal control systems,' Journal of Finance, 43(3): 831-880.

Jensen, M.C. 2000. A theory of the firm: Governance, residual claims, and organizational forms. Cambridge, Ma: Harvard University Press.

Kesner, I.F. \& Johnson, R.B. 1990. 'An investigation of relationship between board composition and shareholder suits', Strategic Management Journal, 11: 327-363.

Klein, P., Shapiro, D.M., \& Young, J. 2005. 'Corporate governance, family ownership, and firm value: The Canadian evidence', An International Review, 13(6): 769784.

KLSE. 2002). Information book. Kuala Lumpur: KLSE Group Communications Division.

La Porta, R., Lopez-De-Silanes, F. \& Shleifer, A. 1999. 'Corporate ownership around the world', The Journal of Finance, 54(2): 471-517.

Lee, C., Rosenstein, S., Rangan, N. \& Davidson, W.N. 1992. 'Board composition and shareholder wealth: The case of management buyouts', Financial Management, 21: 5872.

Lipton, M. \& Lorsch, J. 1992. 'A modest proposal for improved corporate governance', Business Lawyer, 48: 5977.

Mak, Y.T. \& Yuanto, K. 2002. Size really matters: Further evidence on the negative relationship between board size and firm value. Working Paper, National Univ. of Singapore.

McKnight, P.J. \& Mira, S. 2003. 'Corporate governance mechanisms, agency costs and firm performance in UK firms.' [online]URL:http://ssrn.com/abstract $=460300$.

Miller, D. \& Le Breton-Miller, I. 2006. 'Family governance and firm performance: Agency, stewardship, and capabilities', Family Business Review, 19(1): 73-87.

Mishra, C.S., Randoy, T. \& Jenssen, J.I. 2001. 'The effect of founding family influence on firm value and corporate governance', Journal of International Financial Management and Accounting, 12(3): 235-259.

Patton, A. \& Baker, J.C. 1987. 'Why won't directors rock the boat?', Harvard Business Review, 65: 10-12.

Pearce, J.A. \& Zahra, S.A. 1992. 'Board composition from a strategic contingency perspective', Journal of Management Studies, 29(4): 411-438. 
Pfeffer, J. \& Salancik, G.R. 1978. The external control of organizations: A resource dependence perspective. New York: Harper and Row.

Rechner, P. L. \& Dalton, D. R. 1991. 'CEO duality and organizational performance: A longitudinal analysis', Strategic Management Journal, 12(2): 155-178.

Rhoades, D. \& Rechener, P. 2000. 'Board composition and financial performance: A Meta analysis of the influence of outside directors,' Journal of Managerial Issues, 12(1): 7691.

Singh, B. 2009. 'Malaysia's 40 richest', Malaysian Business, February $16^{\text {th }}-29^{\text {th }}$, p.16.

Singh, M. \& Davidson III, W.N. 2003. 'Agency costs, ownership structure and corporate governance mechanisms', Journal of Banking and Finance, 27: 793-816.

Sraer, D. \& Thesmar, D. 2006. 'Performance and behavior of family firms: Evidence from the French stock market.' ECGI Working Paper No. 130/2006, [online]URL:http://ssrc.com/abstract_id=925415.

Sridharan, U.V. \& Marsinko, A. 1997. 'CEO duality in the paper and forest products industry', Journal of Financial and Strategic Decisions, 10(1): 59-65.

Subrahmanyam, V.N., Rangan, N. \& Rosenstein, S. 1997. 'The role of outside directors in bank acquisitions', Financial Management, 26: 23-36.

Weir, C., Laing, D. \& McKnight, P.J. 2002. 'Internal and external government mechanisms: Their impact on the performance of large UK public companies', Journal of Business Finance and Accounting, 19( 5\&6): 579-611.

Yammeesri, J. \& Lodh, S.C. 2004. 'Is family ownership a pain or gain to firm performance?', The Journal of American Academy of Business, 4(1/2): 263-270.

Yeh, Y.H., Lee, T.S. \& Woidtke, T. 2001. 'Family control and corporate governance: Evidence from Taiwan', International Review of Finance, 2(1/2): 21-48.

Yermack, D. 1996. 'Higher market values of companies with a small board of directors', Journal of Financial Economics, 40(2): 185-211. 
